Imágenes en Medicina Intensiva

\title{
Falsa imagen de neumotórax en radiografía simple
}

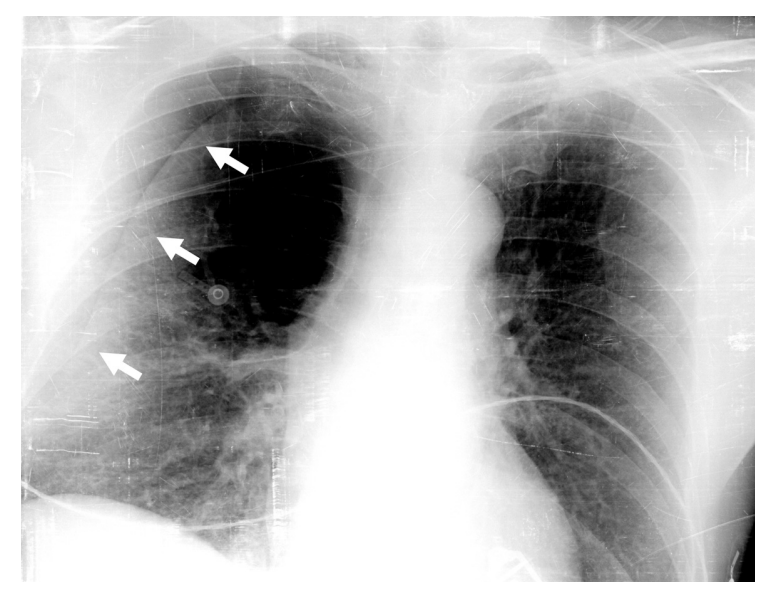

Figura 1.

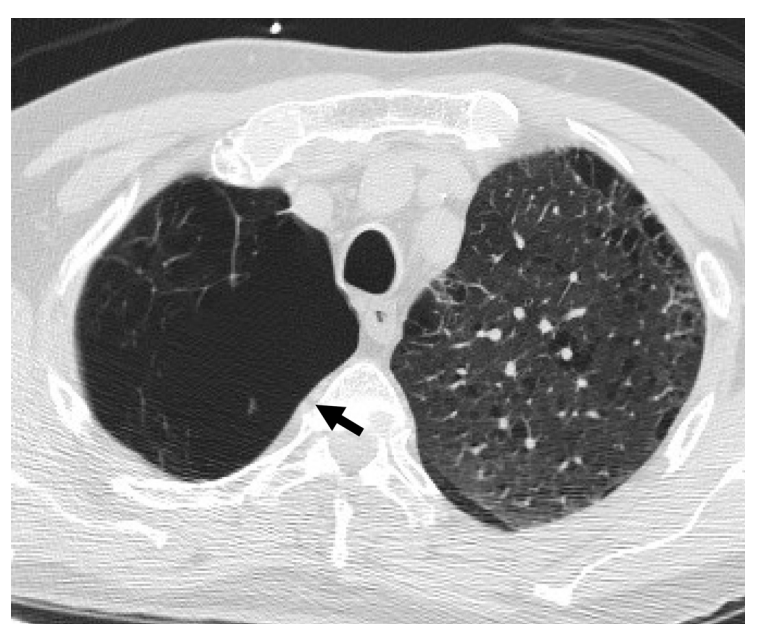

Figura 2.

Se trata de un paciente de 73 años de edad, con antecedente de enfermedad pulmonar obstructiva crónica tipo enfisema, que acude a Urgencias por un cuadro de hemoptisis de 24 horas de evolución. El paciente no tenía dolor torácico u otra sintomatología en la anamnesis dirigida, ni en Urgencias presentaba datos de insuficiencia respiratoria reagudizada. En la radiografía inicial (fig. 1) se aprecia una clara línea de neumotórax derecho. Sin embargo, dada la ausencia de datos clínicos de insuficiencia respiratoria se decidió realizar una tomografía axial computarizada torácica (fig. 2) con la que se descarta la existencia de neumotórax, explicándose la imagen por la existencia de una gran bulla apical.

F. GORDO-VIDAL Y E. CALVO HERRANZ Servicio de Medicina Intensiva. Fundación Hospital Alcorcón. Madrid. España. 